\title{
An Armenian Magico-Medical Manuscript (Bzhshkaran) in the NAASR Collection
}

\section{Citation}

Russell, James R. 2011. An Armenian magico-medical manuscript (bzhshkaran) in the NAASR Collection. Journal of the Society for Armenian Studies 20:1-20.

\section{Permanent link}

http://nrs.harvard.edu/urn-3:HUL.InstRepos:10880592

\section{Terms of Use}

This article was downloaded from Harvard University's DASH repository, and is made available under the terms and conditions applicable to Other Posted Material, as set forth at http:// nrs.harvard.edu/urn-3:HUL.InstRepos:dash.current.terms-of-use\#LAA

\section{Share Your Story}

The Harvard community has made this article openly available.

Please share how this access benefits you. Submit a story.

\section{Accessibility}




\title{
AN ARMENIAN MAGICO-MEDICAL MANUSCRIPT (BZHSHKARAN) IN THE NAASR COLLECTION
}

\author{
JAMES R. RUSSELL
}

"Un document est un témoin; comme la plupart des témoins, il ne parle guère que lorsqu'on l'interroge." ("A document is a witness; like most witnesses it barely says a word until it is questioned.")

- Marc Bloch, "Pour un histoire comparée des sociétés européennes," Mélanges historiques I, Paris, 1969, 16-40, 20.

1.

In the summer of 2009, Dr. Levon Boyajian of New Jersey, born in 1929 in Washington Heights, a neighborhood in upper Manhattan, New York City, donated several old and rare Armenian books, including a manuscript, to the National Association for Armenian Studies and Research (NAASR), in Belmont, MA. ${ }^{1}$ They were brought to the U.S. shortly after his birth by his maternal grandfather, Levon Nazarian, who was the youngest of three brothers and a native of Chemishgezek. The family had moved in Nazarian's childhood from western Armenia to Aleppo, Syria, where he grew up: he emigrated to New York in 1930, worked as a confectioner to help support the family during the hard times of the Great Depression, and died three years later. The books were part of a larger collection, most of which Mr. Nazarian donated to libraries in the new republic of Soviet Armenia when he left Syria. He had run an inn-described as a khan or caravansarai-where he sheltered relatives left destitute in the wake of the Armenian Genocide. His best friend had been a rebel fighter from Zeitun, where Armenians had defended themselves against the depredations and extortions of the Ottoman rulers and their Kurdish enforcers; and he always maintained an interest in progressive politics.

Grandfather Nazarian's wide-ranging interests embraced also the occult. This is not surprising, considering that esotericism challenges the bounds of conventional belief about the order of the universe much as political radicalism questions the smug assumptions of the prevailing social order. And Dr. Boyajian said he had compiled a notebook containing esoteric symbols.

\footnotetext{
${ }^{1}$ A version of the first part of this study was published as "Collection of Books Donated to NAASR by Dr. Levon Boyajian” in the NAASR Newsletter, Belmont, MA, Fall-Winter 20092010, pp. 1-3.
} 
Dr. Boyajian when we last corresponded was unaware of its whereabouts, even whether it was still extant. He passed away in 2010; and the notebook has turned up in a collection of the family's Armenian books donated to the library of NAASR by his son. Mr. Nazarian was a well educated and civilized man: he raised his daughter Verkin, the woman who was to be Dr. Boyajian's mother, in an environment of comfort, enlightenment, and respect. She came to America in 1923. Dr. Boyajian's father Apkar was born in Chemishgezek in 1890 and came to the US before the outbreak of World War I. His was the itinerary of many Armenian immigrants: he worked in a New England textile mill, then as a photoengraver in New York City.

The ancient town of Chemishgezek (Armenian Ch'mshkatsag), home of the Byzantine emperor John Tzimisces, is NNE of Malatya, SE of Akn, and NNW of Kharpert; Aleppo is SSW, twice the distance of Malatya. The city is in the Dersim (now renamed Tunceli by the Turkish state) region of Western Armenia, a stronghold of the Zaza people. These are speakers of the dialect of Dailam in northern Iran and call their speech dilmi; but they are now identified culturally and politically with the Kurds. Legend has it that Dersim got its name from Der Simon, an Armenian priest who accepted the Alevi Shi'a sect of Islam to save his flock, during the Jalali uprisings of the 17th century that convulsed all of Anatolia. There were close ties between the Armenians and Zazas of the region, which is still in sporadic rebellion against Turkish control. The history of the town ${ }^{2}$ mentions both the Boyajian and Nazarian families, whose children united in wedlock. Others there were bibliophiles: Harut'iun Ajemian, a priest from the nearby village of Sisna, "died a very old man and left many manuscripts". 3

Dr. Boyajian's family memoir, Hayots Badeevuh [i.e., Hayots' pative, (Armenian honor)]: Reminiscences of Armenian Life in New York City (Reading, UK: Taderon, 2004), provides a vivid picture of Armenian life in uptown Manhattan in the years of the Great Depression. Times were hard, but the photoengravers' union to which his father belonged helped struggling members of its brotherhood and gave workers a sense of dignity. In their spare time, men sat around debating politics on the sidewalk of Wadsworth Ave., or at coffee houses and clubs, and played tavlu (backgammon). Friends visited each other's homes back and forth, and there was always a jezve-a pot of Turkish coffee - on the stove. Toasts were offered in homemade oghi (the anisette liqueur also called arak or raki). The center of social life was, thus, the family; and the center of communal life was the Armenian Apostolic Church. The Holy Cross Church of Armenia on West 187th St., between St. Nicholas and Wadsworth Avenues, sponsored an annual picnic in June and a bazaar in November; so church events and family life, shared meals, picnics, and the cultural-social-national luncheon-dinner-reception called the hantes

\footnotetext{
${ }^{2}$ Haykazn G. Ghazarean, Patmagirk' Ch 'mshkatsagi (Beirut: Hamazgayin, 1971), p. 575.

${ }^{3}$ Ibid., p. 502.
} 
(Arm. handes, "gathering, occasion, encounter") held the community together and determined the rhythm and pattern of life outside the workplace. Other outings might include breakfast at the Horn \& Hardart automat on 181st St. on Saturday after the cashing of Dad's paycheck. The neighborhood had a half dozen Armenian groceries; ${ }^{4}$ and "Doc" Cohen, the local pharmacist, had the young Levon write out for him in English transliteration the Armenian of the six hundred words that, according to The New York Times, were basic to any language. There were many single men in the community who had either never married, or who had lost their families in the Genocide; and their fellow Armenians took care of them.

The life that Levon Boyajian recalled is not very different from that of other ethnic enclaves in New York then. This writer's mother grew up in Bensonhurst, an Italian and Jewish neighborhood of Brooklyn. In the years of the Great Depression, a nickel or dime was a treat went a long way on a weekend trip to the automat, or the movies, or even Manhattan. Home and family were the anchor of existence, and, as with the Armenians, the familiar foods of the old country gave people a sense of stability and warmth in a frightening world. My grandmother Marguerite cooked the Moroccan Sabbath stew called adafina, baked kadayif, and served guests little cups of Turkish coffee with homemade candied orange peel. By shopping for groceries wholesale and finding chicken wings and necks cheap, and God knows what other strategies, Grandma managed to put food on the table every night for parents, grandparents, four daughters, several sisters, their families, and friends. The hard roscas and fijuelas I remember from my childhood were made with recipes brought to Salonica from the Spain of Ferdinand, Isabella, and the Inquisition five centuries earlier. During Prohibition my grandfather made wine and raki at home; and when I was a boy Grandma entertained me and my cousins with tales of Djuha, the crafty dervish Hoca Nasrettin know so well to Armenians, too. And though I was too young to have heard him, Uncle Jack played the oud. As for the occult, my great grandmother Rachel, whose nickname was Manache, used to offer the blood of a black cock to the dead at midnight when somebody was ill. I don't know the other aspects of her witchcraft; but she was an austere and bony woman of immense power who got around on a great staff till she passed at ninety six, having foretold her own death to the day. She loved me and used to say to me when I was little Camina, pasha! "Walk, O king!" in Ladino. I inherited her ring of twined snakes with diamond and ruby eyes. The family had escaped from the famine and great fire of 1917 in Greece, and from the filth and ignorance of Morocco: America, despite the Depression, still meant freedom, goodness, and opportunity in those days. President Franklin Delano Roosevelt and New York Mayor Fiorello La Guardia enjoyed the status of living saints.

\footnotetext{
${ }^{4}$ In my teenage years, around 1970-71, only one was left, the Hay Nparavachar, on St. Nicholas Ave. The neighborhood is now largely Dominican.
} 
I first met Dr. Boyajian when we worked together on the organizing committee of a two-day conference on the sequelae of trauma-the experiences of children of Genocide survivors - that was held at the Armenian Diocese in New York in April 1980. He was then a vigorous man of middle years, a respected physician and psychiatrist, a pillar of the Church, and very friendly and forthright. I was twenty-six, and coordinating cultural affairs for the Diocese was my first job. It was a good job-His Eminence Archbishop Torkom Manoogian and our Director, Syraun Palvetzian, treated me with boundless kindness and courtesy, and the Diocesan staff was a supportive, hard-working, fun family. The conference, which touched upon the Holocaust and Cambodia as well as the Armenian Genocide, was attended by hundreds; and the proceedings, with Levon's study of the sequelae of genocidal trauma, was prepared for publication. It remains still in manuscript, though, and is now in the NAASR archives. Levon and I had a lot in common, for I grew up in Washington Heights, too; and when I interviewed him a few months before his passing we discovered that there were more than a few memories of the old neighborhood we shared and treasured: listening to the Texaco broadcast of the Metropolitan Opera on Saturday afternoons on WQXR through every radio in every window uninterruptedly as we walked down the street, not missing a note. I remember the wonderful hantes in the hall below Holy Cross, where my Armenian teacher, Vart Tarpinian, taught Sunday school. There was a feast of salad, pilaf and roast beef, ice cream and coffee, then impressively intoned prayers and flowery speeches and songs with a lady of a certain age on the piano playing awfully well and dances by kids in lovely costumes and poems, and a lot of loud socializing and good cheer. In midafternoon you would stagger out of Haik Kavookjian hall with the strong conviction, Armenia lives! When I was young, Archbishop Tiran Nersoyan, a great scholar, lived in the parish house attached to the church; and Levon remembered Fr. Yeghishe Simonian, who served from 1935 to 1965: he was a survivor of the burning and massacre of Smyrna, as was Abp. Leon Tourian, whose assassination in the church by leaders of the New York chapter of the Armenian Revolutionary Federation (the Tashnag or Dashnak party) in December 1933 created a rift in the community that lasted for generations and whose echo is still felt. ${ }^{5}$ Indeed the echoes of the grisly crime reached far

\footnotetext{
${ }^{5}$ Marjorie Housepian Dobkin, author of the groundbreaking historical masterpiece Smyrna 1922: The Destruction of a City (Kent, Ohio: Kent State University Press, 1988), about the Turkish massacre and destruction of a great and ancient city, published a memoir of her own Armenian-American childhood in New York, A Houseful of Love (New York: Random House, 1957), that became a bestseller and was serialized in Reader's Digest. Although overly sentimental and sanitized, in my view, the book presents a faithful picture similar to Boyajian's. Marge is the mother of my old friend and Columbia classmate Stephen Andrew Johnson of New York, who told me she answered the phone the day of Abp. Tourian's murder: her family lived a few minutes away from Holy Cross, and her father, a physician
} 
beyond the confines of the Armenian community: in his first novel And The Hippos Were Boiled In Their Tanks, a roman à clef about a murder within the social circle of the nascent Beat movement in the mid-1940's, William S. Burroughs named one of his fictionalized characters Tourian. The very name, after a decade, still evoked the horror of murder.

Washington Heights was not just a big Armenian neighborhood-my teacher, Fr. Krikor Maksoudian, remembered the pun Washington Hayots ", "of the Armenians"-but a center of arts and learning. The scholar and translator of Persian poetry, Mihrdat Tiryakian, whose translation of dastans from the Shah-name of Ferdosi was published in 1951, lived in the neighborhood-he followed in the path of his father Harut'iun, whose Armenian translation of sections of the same epic was printed in New York in 1909. The graphic designer Minas Minasian, who died in 1981, born in the village of Chengiler near Nicomedia, lived on Pinehurst Avenue. His Armenian typefaces and designs defined the poster, periodical, and book arts of the American Armenian community for decades. Harout'iun Hazarian, who lived on Ft. Washington Avenue and 170th Street, died at the same time. He had devoted his considerable wealth to buying Armenian manuscripts and donating them to the Matenadaran in Erevan, and to leading the Gesaria (Caesarea of Cappadocia, Kayseri) Compatriotic Union. By the 1970's, the neighborhood had become dangerous, the children went away to college, and most families moved to the suburbs - to Fort Lee in New Jersey, or Westchester in New York. ${ }^{6}$

The 1930's saw not only the great schism in the Armenian community, which began at the little parish church in Washington Heights, but also the rise of fascism overseas and the eclipse of the Soviet Union by Stalinist tyranny. The convulsions beyond the sea affected Armenian-Americans. Levon averred that widespread anti-Semitism in the Armenian community sometimes precluded sympathy for the Jews in Nazi Germany, but this was by no means a majority sentiment and one member of the community reacted quite differently indeed. Avedis Derounian, a Genocide survivor growing up in Washington Heights, witnessed Abp. Tourian's horrible murder in the church and perceived a connection between the Armenian Genocide, that crime, and the fascist movements gaining strength in Europe and here. Using the nom de plume John Roy Carlson, he wrote a bestseller, Under Cover, about fascist organizations in America. His articles in Fortune on the subject spurred Congress to form the House Un-American Activities Committee. After the war, Derounian traveled to the Middle East to cover the Israel War of Independence and published with Knopf in New York a few years later

who had served as a medical relief volunteer in Armenia in World War I, attended the Primate, who died in the parish house of his wounds shortly after the attack.

${ }^{6}$ See James R. Russell, "The Calligrapher of Washington Hayotz," Ararat Quarterly (New York, Autumn 1981), pp. 24-26. 
From Cairo to Damascus, in which he detailed the transplantation of Nazism into the Islamic world and presciently argued that Islamic political fanaticism would prove to be a far deadlier and longer-lasting threat to freedom than Communism. And meanwhile, as the world surged and darkened and ignorant armies clashed by night and the Armenians of New York worked and ate and prayed and cooked and raised their children, the books waited...

Mr. Nazarian's books were kept with respect in a cabinet, and the family had a Bible and a Narek (that is, the Book of Lamentations of the tenthcentury St. Grigor Narekats'i, a cycle of 95 mystical prayers), as most Christian Armenian homes did. It would appear from the notations that $\mathrm{Mr}$. Nazarian read his books carefully. The seven vowels of Armenian were the subject of a magical text, the Eot 'nagreank', or "(Book of) the seven letters"; and perhaps Mr. Nazarian's interests in esoterica led him to the only manuscript in the initial collection donated by Dr. Boyajian, a seventeenthcentury miscellany that contains two grammatical treatises. One notes that the probable origin of the term "grimoire", the standard word for a manual of magic, is French grammaire, "grammar"! The manuscript contains also Aristotle's letter to Alexander; and this, too, has magical overtones; for their fictional correspondence, which includes advice on the preparation of talismans, is the matter of the magical book known in the West as Secretum secretorum, "The Secret of Secrets." The occult notebook of Mr. Nazarian was donated posthumously to NAASR, as noted above, by his son. But the principal books donated by Dr. Boyajian shortly before his death are these:

a. A manuscript on paper of roughly octavo size, containing texts in several hands. The first, with title in purple and red and text in black, is, "Definition of Grammar: Grammar is an art comprised of speech and writing and its parts are four: letter, syllable, word, saying..." in an attenuated notary, Arm. notrgir, of the early 17th century, concluding with an undated colophon, "Remember this sinner in Christ." The next text is in a considerably cruder semi-cursive sheghagir hand of the 17th century: "Grammar is a skill, those matters of the poets and of oft repeated utterances, and its parts are six: first, writing..." There follows in a neater, mixed notrgir and sheghagir of the same period, "The letter of Aristotle the Philosopher to king Alexander. History concerning the world [ashkhari for ashkharhi]. Alexander often seemed to me to be something truly divine..."

The book is completed in this same hand but with less space between the words, and concludes with a colophon: "And now God, as the saying of the ancients goes, is the beginning and the end. And, having within Him all beings, He completes their paths in a straight way, causing them to follow the various kinds of their natures. Falling short of justice they are punished by God; and likewise whoever is favored will be blessed with His grace. Eternal glory, Amen. This was written in the Armenian year 1096 in the month of 
May, at a time when one Sultan Epram [Ibrahim] reigned, who fought a war against the Cretans and all the land of the Ottomans endured great suffering. And all the more so this city of Halap [Aleppo], for the Pasha was particularly lawless. They called him by the name Tali Husen [i.e., dali, Mod. Tk. delli, Huseyn, "Crazy Hussein", a typical Jalali sobriquet]. If only God might free all faithful Christians from the hands of these people by the intercession of the Holy Mother of God, Amen." There follows in Arabic language and script: $\mathrm{Al}$ faqir qasis [keshish?] Markar. "The poor man, the *priest Markar."

The surface leaves of the cartonnage from which the hard cover was made were manufactured using an older MS in very fine bolorgir script of a type found in Cilician MSS of the early 14th century; but as the thin, polished paper feels to me more recent, I am inclined to date it to the 17 th century or not much earlier. The text has a superscription in modern cursive Armenian, perhaps belonging to Mr. Nazarian: "Menologium, martyrology of our holy father Gregory the Armenian of the family of the Illuminator and a most select martyr. History." The book bears two stamp seals, one of which seems to have the Armenian name Kirakos; and on the flyleaf in purple ink is this note in the same flowery hand as the superscription on the cartonnage: "I took (this) from Brutean (the potter?) Kir[a]kos in the monastery of St. Sargis, abbot of the Armenians, 1882 February 20 yitisisia (in Edessa?) Arewin [?].” The text of the Menologium, which is evidently the martyrdom of the Apostle Bartholomew, is as follows: "... who went after him. Take those deceivers there outside. And the executioners went... apostles... took Philip and Bartholomew, and Mary, and dragged them outside. And when the tyrant beheld them he began to gnash his teeth, and said, Pull away those witches, who are leading astray many women and virgins. And they said, We are worshippers of God. And he commanded.../ ... your deeds. And let go your life full of pain. And abandon your fleeting joys. For it passes like a shadow. See that which endures, and forget these transient things. And give up your savage ways, that is, the deeds of foulness, that..." And at the other end, "She went outside and saw them. She made bold [hamardzets'aw for hamardzakets' $a w]$ before them all and said, I am a Hebrew and the daughter of a Hebrew [ebraets' $o$ for ebrayets 'woy]. Speak to me in the speech of my fathers. For I have listened before to your preaching and was healed of my disease. And now I glorify and bow down to the beneficence of your God even in this distant land, for the precious stone of one's own that the great dragon swallowed. But Lord, make alive the true stone..." Next page, “... they led astray the multitudes. For after that they went in to him. This city was full of useless people. The slew also the serpents, the sons of the viper, who were our gods [i.e., false gods, Arm. atsk' with a patiw below the abbreviation, as is done with the name of Satan]. They destroyed our temple and our worship perished. Our table, too, was ruined, and no longer do we find wine to place before us. For having drunk of the..." 
b. A printed Sharaknots ' (Hymnal) illustrated with woodcuts, as of Adam and Eve deceived by the serpent (p. 130). Following the table of contents on p. 240, the endpaper contains a fragmentary inscription, "May there arrive.../ Khumkhabu [Kum kapu in Constantinople, site of the Armenian Patriarchate]/ Khan and/ Lord Grigor/ T(i)r(a)ts ' $(o) w$ [a cleric without ordination]..." Following p. 716, Es em ch 'imish/ kezakts 'i/ terats ' $u$ / arut' [iw?]n/ girets 'i/ $t$ 'vin "I, the tirats ' $u$ Harut'iun of Chimishkezek wrote this in the year..." In pencil there follow the numbers, in Arabic:

1928

1096

832

1096 is the Armenian date of the MS described above, to which one adds 551 to obtain the date Anno Domini; but it would seem Mr. Nazarian subtracted it from AD 1928 - two years before his departure for the US from Aleppo - in what appears to have been a misguided attempt to ascertain when the colophon was written.

c. P'elik's ew Pawlině kam Zhuray lèran taki gerezmaně (Felix and Pauline or, the tomb below Mt. Jura(, translated from Italian (into Western Armenian) by Grigor T'orosean (Paris, 1859). It is inscribed, Ar nazeli or. Zmrukht Nazarean, $i$ nshan burn zgats'mants' nuirě sirakarot khosets 'ealn iwr V. M. K'iwrk'chean, "V.M. Kurkjian, her intended, pining for love, offers this in token of his ardent feelings to the charming Miss Zmrukht Nazarian" with the date 1887 March 2, Constantinople. Dr. Boyajian does not know who the swain and his lady were; though perhaps Ms. Nazarian was a relative. The novel was written by Pierre Blanchard (1772-1856). Ms. Shushan Teager of Belmont, MA, a native of Beirut whose family were from Aintab, has identified the ardent swain as none other than Vahan M. Kurkjian, the author of A History of Armenia, Aspet Liparit, and other books. The young lady, whose family settled on the form Nazaretian of their surname, was first cousin to Ms. Teager's grandmother, Zarman Nazaretian. The Nazaretians settled in New York City.

d. A collection of miscellaneous political tracts bound together:

1. Sots 'ializmé ew sots 'ialakan sharzhumé 19-rd darum (Socialism and the socialist movement in the 19th century), translated from (Werner Sombart's study in) German and published by the Armenian students of Geneva, press of the Armenian Revolutionary Federation, 1898, with the epigraph Och 'inch " ch'em arajarkum, Och'inch' ch'em ent'adrum, patmum em (I propose nothing, and I suppose nothing: I merely relate). 
2. John Stuart Mill, Azatut'ean masin (On Liberty), translated from the Russian translation, with a brief account of Mill's life (Moscow: Herbek Press, 1898).

3. S.S. Zak, Hogh hew kapitalizm (Land and Capitalism), translated from Russian (Tiflis, 1907).

4. Yovhannes Kh. Nazarean, Krt'akan veratsnut 'iwn (The Renaissance in Education) (Constantinople, 1909).

5. H. T'. Bokl (Buckle), Angliayi k'aghak'akrt'ut'ean patmut'iwnĕ (The History of the Civilization of England) (Tiflis, 1909).

The latter miscellany suggests that Mr. Nazarian was interested in economic history and in progressive politics in particular. This was not at all uncommon: Karl Marx, in a preface to a late edition of his Communist Manifesto, mentioned two Armenian translations of his work that he had not seen since they had been confiscated by the Ottoman police. Both Western and Eastern Armenian printed versions of the Manifesto are known; and Armenian socialist and revolutionary activity is coextensive with that of the Russians themselves. In the US, especially during the 1930's when so many people were out of work, the Hnch 'ak party ("Bell", named after Alexander Herzen's Kolokol) and the Communist Harajdimakan (Progressive) league were active in calling for reform or even overthrow of the capitalist system. There were even Armenian translations of Trotsky's tracts of the Fourth International published in New York. And when the American Lincoln Battalion fought with the International Brigades against fascism in the Spanish Civil War, one of several Armenian Americans who died in battle was Ashod Antreassian on New York. His brother named the Ashod Press, which served the Armenian Diocese for decades, after the fallen hero.

So as the fledgling Armenian-American community weathered the storms of political assassination and economic depression while building its thriving, vital culture in New York City, a cabinet in an apartment held a manuscript whose scribe evokes the cataclysmic events of the Jalali uprisings of the 1600's, decades before New York received its present name. A printed hymnal records its acquisition by a man of Chemishkezek from a lay priest. A romantic novel gives a brief insight into a romantic engagement in late 19thcentury Constantinople. The latest text in a collection of political studies and tracts is bound in 1909-the terminus date for the miscellany, i.e., in the turbulent period of revolution in Russia, Iran, and Ottoman Turkey and the portentous year of the Adana massacres, scarcely half a decade away from the holocaust that was to destroy the millennial life of the Armenians in most of 
their homeland and scatter the survivors across the globe, as far as upper Manhattan and New England.

For decades, the books brought to the shores of the New World from Aleppo were kept carefully as life roiled around them. Men worked, women cooked and brewed coffee, there was laughter and conversation, and sorrow and longing. Children played, grew up, studied and became professionals, Americans. The neighborhood changed and most of the Armenians moved away. The Holy Cross Church of Armenia still stands, but most of its parishioners come to Sunday services by car from suburban homes. And as for the grocery stores, the large Sunday crowds, the inviting smells - all that belongs to the past. Though the bloodstained vestments of Abp. Tourian are still stored near his tomb in the church, and the dark tale of his grisly murder still can shock one, it is swiftly fading away to ancient history now, and as the Soviet era itself recedes into memory and an independent Armenia confronts new challenges, the wounds of old political feuds within the community are healing. But the old Armenian books, like folded flowers waiting through the night for dawn, waited patiently on their shelves. And now the books open, and speak to us again.

\section{2.}

One of these is Dr. Nazarian's newly discovered notebook containing those esoteric symbols that his grandson thought was lost. Its title-page calls it bzhshkaran, a book of medicine or healing; but it is perhaps better described as a magico-medical miscellany. The manuscript is inscribed in a small, sturdy hardbound brown notebook, probably of late 19th or early 20th century manufacture. The pages, about 100, of which 89 are inscribed, are ruled in squares like graph paper and measure 3.8 inches $(19 \mathrm{~cm})$ by 4.8 inches $(24$ $\mathrm{cm}$ ). There are four sections: a collection of remedies (pp. 1-49), a series of spells (pp. 50-64), a list of Psalms to be recited as magical texts for various purposes (pp. 66-73 and 81-88), a long disquisition on the medicinal and magical uses of parts of the stork (aragil) (pp. 74-78), and two loose inserts. The latter section, following instructions on using the liver mixed with oil to cure the possessed and keeping the wing to chase depression from one's heart, concludes with the laconic instruction to keep the "inner beak" (znergin ktuts'n) with one: bave imastnots" (to the wise it is sufficient). Verbum sapienti indeed.

The phrase reminds one at once of the title Angitats ' anpet (Useless to the ignorant), that the great fifteenth-century Armenian physician Amirdovlat' of Amasia assigned to one of his tracts. Medicine requires skill and knowledge, many of its methods and ingredients are not indeed to be disclosed to those who might foolishly or maliciously misuse them, and some of its operations seem magical still. But Amirdovlat' did not intend his craft to be esoteric; as 
other compositions, Usumn bzhshkut'ean (The study of healing) and Ogut bzhshkut "ean "The usefulness of healing", demonstrate. He believed the physician's art was useful to the body as prayer was, to the soul; and closed a tract with a brief poem: Yorzham sharzhmunk' lini ts 'avots " Ev estatsem est pitoyits " Ev Astuats tay zaroghjut"iun est hachoyits" "When the symptoms of pains appear/ Then I provide the needed care;/ And God bestows health, if it pleases Him." In his manuals for treatment, Amirdovlat' lists each disease, then its cause, its signs, its treatment (statsum), and the opinions of various previous Greek, Arab, Persian, and Armenian experts. The famous Mkhitar ${ }^{6}$ Herats'i figures among the latter. The title bzhshkaran or an Arabic equivalent in Armenian, Akhrapatin, is fairly common in Armenian medical books, such as that of Grigoris, late fifteenth century, each chapter of whose book is called a "door" (durn), suggesting a Muslim source: Arabic bab or Persian dar. Armenian doctors were prominent in the Ottoman Empire and elsewhere, and the tradition is long: in the late 18th century, for instance, Petros $\mathrm{K}^{\prime}$ 'alant'arian, born at New Julfa in Isfahan, traveled to Moscow to study medicine. His "concise" (hamarot) bzhshkaran contains sections on emetics and laxatives, fever, stomach ache, liver ailments, problems of urination and ejaculation (sermnakat'ut'iun), headache, cuts and wounds, skin diseases, and problems of the eyes, ears, teeth, and musculature. He frequently transcribes Latin terminology in Armenian script, and uses some Russian, too (petrushka, romashka) for herbal matters. ${ }^{7}$ It is easy to imagine him taking a walk in the forests outside Moscow with a Russian friend on a beautiful bygone day, learning about plants and probably picking berries and mushrooms.

So Armenian medicine and medical books as such have a long pedigree; ${ }^{8}$ and it is likely that the copyist of our text worked from one or more of these, adding French words where a modern source indicated them or as he himself knew them. But the manuscript has two other sections, on spells and the magical employment of Psalms. These suggest still deeper, more ancient, springs. And such a mixture of relatively modern medicine, medieval magic, and magical use of Biblical texts is actually not at all strange or surprising, any more than was the interest of the compiler of our bzhshkaran in these subjects. For in fact little in human culture is older than the association of magic and medicine. One of the spells in our manuscript invokes Solomon, the ancient king of Israel whom Jews, Christians, and Muslims alike regard as the greatest magician in history. Jewish tradition attributes to Solomon's authorship a book (sefer) or table (tabla) of remedies (refu'ot) for every

\footnotetext{
${ }^{7}$ See Arak'el G. Arak'elyan, Hay zhoghovrdi mtavor mshakuyt'i zargats 'man patmut'yun, Vol. 2 (Erevan: Haypethrat, 1964), p. 374 ff.

${ }^{8}$ Hakob S. Anasyan, Haykakan matenagitut'yun (Armenian Bibliology), Vol. 3 (Erevan: Haykakan SSR GA Hratarakch 'ut'yun, 2004), includes detailed discussions of 89 MSS and printed books on medicine, together with an extensive bibliography (to p. 75) of secondary sources on Armenian medical literature and practice.
} 
disease. Towards the end of his life Solomon is said to have repented of his errant ways and consigned many of his writings to a great bonfire; but Hezekiah is supposed to have "concealed" the Sefer Refu'ot: the verb used is ganaz, an Iranian loan meaning "treasure" (Pers. ganj, Arm. gandz, etc.); and one recalls the derivative geniza, a storeroom for worn-out sacred texts. The Church Father Hippolytus cites an old tradition, repeated later and independently by Maimonides, to the effect that Hezekiah consigned the book to occultation (but did not destroy it!) because people had come to rely on it, rather than on God, for healing. ${ }^{9}$ Just as for centuries magicians have produced magical books purporting to be the Seal of Solomon, which probably never existed; so the original of the book with which we deal now might have purported to be a revealed text of the Sefer refu'ot, whose actuality is likewise doubtful. Myths are inherently impossible, though meaningful; but legends can have a plausible basis in reality. It is at least possible that the sick sought the aid of king Solomon; for since time immemorial in diverse countries people have believed that the touch of a monarch can cure such tellingly-named ailments as the skin disease called in English "the king's evil". From there, the claim to be able to cure all diseases is but a hubristic expansion, to which would then be attached Solomon's reputation as the author of thousands of books.

Solomon is often identified in Iranian and Islamic lore with the primordial king Jamshid (Avestan Yima khshaeta "the shining", the equivalent of the Vedic lord of the dead, Yama), to whose hubris and fall from grace Zarathustra referred enigmatically in his hymns, the Gathas, probably in the late second millennium B.C. In later tradition, though, it is made quite clear that Jamshid demanded men worship him as God since he could cure every disease. Though one may dispute who inspired whom in the development of the legend, the Hebrew God is often death-dealing while the Persian Ahura Mazda, an entirely benevolent being, never is. So although both divinities are healers, the source of this particular detail of the Solomonic cycle may just be Iranian. Solomon's legendary medicine had a magical aspect, too- yet another reason for remedies and spells to rub shoulders in the Armenian Bzhshkaran. Josephus reports that in the presence of the Roman emperor Vespasian a Jew named Eleazar employed an incantation (Gk. epode), Solomon's name, and a root (probably the famous baaras) prescribed by the latter, to draw demons out of possessed men. And as for the third portion of our manuscript, the list of Psalms and their magical uses, one need only recall Josephus again: David was able to heal and exorcize Saul because he could charm away (Gk. psallein, cf. the word Psalm) spirits with his harp (Ant.

\footnotetext{
${ }^{9}$ See David J. Halperin, "The Book of Remedies, the canonization of the Solomonic writings, and the riddle of Ps.-Eusebius," Jewish Quarterly Review 76.4 (Apr. 1982), pp. 269-292.
} 
6.166-169). ${ }^{10}$ One can scarcely criticize a pious Armenian for employing the Psalms to magical ends when their author did the same himself.

The title page, with the single word Bzhshkaran (Compendium of remedies), is followed by 46 pages listing diseases, their symptoms, and treatment, written in purple ink with a sheghagir cursive hand. Three additional pages of the same in pencil and black ink by the same hand follow. The language is Modern Western Armenian; and the names of diseases and medications are given also in French in parentheses. This would suggest that the manuscript was compiled at Aleppo: Syria after the first World War was French mandate territory according to the terms of the Sykes-Picot agreement that divided the Arab spoils of the Ottoman Empire between Britain and France. Since Dr. Boyajian claimed that the notebook was compiled by his grandfather, one can assert beyond reasonable doubt that the hand was $\mathrm{Mr}$. Nazarian's own; and he wrote the notebook most likely in the 1920's, in Aleppo. The remedies in the first section are generally of the sort available at home (strong coffee and the like) or easily obtained at an apothecary shop in the days before sulfa drugs and antibiotics were discovered; and one supposes that the laboriously copied text was put to practical use. The first sickness addressed is migraine (glukhin kes ts'av), for which sitting in the dark is recommended as the cure (darman), with a cachet of antipyrine or quinine sulfate. Treatments follow for various complaints including hemorrhoids (with the Turkish term for the complaint, mayasil, helpfully appended), constipation (pndut'iun), drowsiness, drug-overdose (cocaine, morphine, belladonna, and laudanum), arsenic-poisoning, fish-poisoning, mushroom-poisoning, tuberculosis (with progressive symptoms carefully listed), epilepsy, colic, seasickness, cholera, hair loss, skin disease, rheumatism, shortness of breath, brain fever, brain hemorrhage, abscesses, neuralgia, stomach ailments, bronchitis, chills, cystitis, angina pectoris, athlete's foot, and a fever called "snake disease" (odzakht, Tk. ilanjik) whose symptoms include trembling, vomiting, and redness of the nose. For the latter ailment bzhshkin ts 'oyts' tal - a visit to the doctor-is recommended. The added pages in pencil and black ink address eye problems, toothache, and cuts. An example from p. 4: Belladone [French, i.e., Belladonna]: nshan-beraně ch 'or ev ach ' $k$ 'in biberě

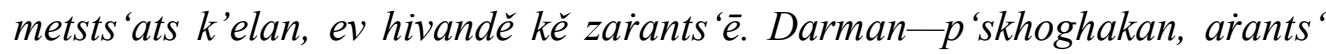
shak'ari zoravor surch talě $v$ hivandě tak'ts 'nel. "Belladonna: symptommouth dry and pupils of the eye dilated. The patient is raving. Treatmentemetic, keep the patient warm and give him strong coffee without sugar." On p. 9, one is advised to administer "Bromhydrate de quinine, antipyrine" to treat a fever; and if the patient is spitting up blood, saroyts 'i pok'ri(k) ktorner kllel tal (have him swallow little bits of ice). As a cynical Scottish convert to

\footnotetext{
${ }^{10}$ See Dennis Duling, "The Eleazar Miracle and Solomon's Magical Wisdom in Flavius Josephus' Antiquitates Judaicae 8.42-49," Harvard Theological Review 78.1/2 (1985), pp. 125, esp. pp. 2, 4, 22.
} 
Orthodoxy swinging a censer in a Moscow church was once heard to mutter in between verses of the Old Slavonic liturgy, "If it does ye nie goud, it'll do ye nie harm!"

Pages 50-64, in pencil and black ink, contain a series of magical spells in semi-Classical and Modern Armenian interspersed with lines of magical symbols or grids of the same that resemble magic squares but have only a few actual numbers (in Arabo-Muslim numerals, with occasional Western ones) in each example. These numbers don't add up; so the magical squares were either copied wrong or were gibberish from the start. The medical portion of the book is written in somewhat smaller letters, but the hand seems to be the same. "(50) By the command of God Elijah the prophet lived in heaven 7 years and 6 months. ${ }^{11}$ Solomon the wise bound the (fiery red?) giant ${ }^{12}$ and all the (legions?) ${ }^{13}$ of the demons he submerged and bound in the depths of the sea. Joshua bound the feet of the (son's king?) the sun; ${ }^{14}$ Daniel the prophet bound the mouths of the lions; (51) and as Moses the prophet parted the Red Sea and bound the same with fetters, I bind you, evil t pghas, ${ }^{15}$ with the three nails and the milk of Mary the virgin, and as (52) the Lord Jesus Christ bound the evil Satan, so bound with the same fetters stand you before the keeper of this holy writing, $\mathrm{NN},{ }^{16}$ in immovable fetters, in seven chains, and by the name of the holy tree of life of the Cross of Christ and of the Father and of the Holy Spirit, Amen. The holy Mother of God came and brought 300 (legions?) of iron. (53) Keep this writing with you: your fortune will open and you will be beloved before every man. The name of the Father and the Son and the Holy Spirit, Amen. God the Father, creation of Adam. The beauty of Joseph was sweetened before Pharaoh. The Sole-Begotten Son was sweetened, salvation of the world was sweetened as at the love of Solomon for wisdom the bee was sweetened at its labor. So sweet before all men be (this person's name). God had mercy on us and blessed us as his heaven in us, and have mercy on us. (54) End. [Magical symbols] (55) For stomach ache write, God, strengthen a pure heart within me and renew the soul in my breast straightly.

\footnotetext{
${ }^{11}$ I have not found another version of this spell; but in general it resembles other binding spells that list Biblical precedents; cf. Frédéric Feydit, Amulettes de l'Arménie Chrétienne (Venice: St. Lazarus, 1986), no. XCI (p. 256 f.).

12 The text is unclear but seems to read *hrashek $k$ 'ajn. There are Armenian spells against the shek mard "red man" or shek ach 'k'avor "red-eyed man": see Sargis Harut'yunyan, Hay hmayakan ev zhoghovrdakan aghot'k'ner (Erevan: Erevan University Press, 2006), p. 84. According to the superstitions of many peoples red-haired people are dangerous or unlucky; and mediaeval Germans believed that demonic rote Juden, "red Jews" living outside the wall Alexander built to confine Gog and Magog were to burst forth as the army of the invading Antichrist.

${ }^{13}$ Arm. *gunds, indistinct and crossed out before gen. pl. divats '.

${ }^{14}$ This refers to the miracle at Gibeon, Joshua 10.12-13.

15 The t"pgha and al are mythical beings, the "child stealing witches" of Armenian and general Ancient Near Eastern mythology who make women sick in childbirth.

${ }^{16}$ Arm. filan, i.e., the Turkish form of a loan from Arabic, fulan "somebody, so-and-so".
} 
Write it all, then this [magic square]. Save me from sickness, God, God of my salvation and so on. (56) This writing is for a journey and a robber and the sea and harm done by witches. [Magical symbols] (57) [Blank] (58) [Blank] (59) Write for falling in love: Take red copper, write this talisman on it and write the name of the person desired, then cast it into fire, and say, May the heart of $\mathrm{N}$ of $\mathrm{N}$ burn for my love like this talisman. It will burn. By God $^{17}$ he will get up and come. [Magical symbols] Write this on a stone also and cast it into fire. [Magical symbols] And say, May the heart of $\mathrm{N}$ of $\mathrm{N}$ burn for my love. By God he will get up and come. (60) Write this and put it on your forehead. [Magical symbols] In order to kill your enemy, write these 6 letters on an egg and bury them in a field. The hour of your ill-wisher's death will be the hour he looks upon it. [Six magical symbols] And with (?) ${ }^{18}$ incense burn for its ${ }^{*} \operatorname{star}^{19}$. (61) If they want somebody's daughter and they do not give her away, write this talisman, write the names of the people in that house along with it in a green bowl. ${ }^{20}$ Then pour water over it till it is full. Let the boy who wants the girl wash in it, then take the water he has washed with, and pour it at the girl's door. By God, the desired girl [magical symbols]. (62) [Crossed out: If you want somebody to...] Releasing the binding of a bridegroom... ${ }^{21}$ Clap your hands: Heavenly God, the 'Render power' and write the name next to it on two pieces of paper. Let the groom and his bride wash with the first piece. Let the groom bind the second to his right arm and by God he will be released. Here they are: Hasavigh, mat'um, marum, mat 'eumn, mariun, mahk'on, avasi, azavmi, marut ' ${ }^{22}$ By God he is released. (63) [Magical symbol] Write this on

\footnotetext{
${ }^{17}$ Arm. inst. sg. A(stutso)v, that is, "with God's help." This abbreviated, pious formula is repeated throughout.

${ }_{18}$ Arm. $u$ tsats.

${ }^{19}$ A symbol meaning "star" — an X with a dot in each angle (see Ashot Abrahamyan, Hay gri ev grch 'ut'yan patmut' yun (Erevan: Haypethrat, 1959), table on p. 169) — is the only one used in the body of the text, as opposed to the separate talismans that follow each spell (one of which, on p. 54, includes it); and this is the only instruction to burn incense, presumably at a time indicated by an astrological calculation.

${ }^{20}$ Arm. ch 'anakhi; variant ch 'ank' $i$ partially erased. The first form is a Central or Eastern Anatolian pronunciation of standard Turkish çanak, "bowl." The second form might have been erased as it could be confused with Tk. çünki, "because." Aside from a particular color, the type of bowl is never specified in these spells; nor am I aware of the existence of Armenian inscribed magic bowls of the sort found in ancient and late antique Mesopotamia and, for instance, in modern Iran.

${ }^{21}$ Followed by unclear words: zay erig tun ev aghmun (?)

${ }^{22}$ This rhyming concatenation of vaguely Arabic magical words is mostly nonsense save perhaps for the final one, which may be the name Marut. Harut and Marut are the Armenian (or Sogdian, though distance makes this less likely) forms of the Middle Iranian names of the Zoroastrian Amesha Spentas ("Holy Immortal" archangels) that preside over the plants and waters, Haurvatat and Ameretat. They replace in the Qur'an the twin angels Shemhazai and Azael of Jewish demonology, who dwell in a cave and teach magic to all comers. What is interesting is the appropriateness of the name to the magical rite, for on Ascension Eve, Armenian girls take petals of the flower horot-morot and place them, with various personal
} 
your beloved's [crossed out: she will come] threshold on the first Wednesday of the moon [=month?] and bury it there. By God, she will come. Keep it on you and you will be beloved of all men. [Magical symbols] (64) [Magical symbols] End."

Page 65 is blank and the text resumes with the third section on p. 66, a list of Psalms and their uses written hastily in large letters in pencil: "(Vol.?) 1 ch. $^{23}$ For going to court; Vol.(?) $6 \mathrm{ch}$. For not being harmed. (67) Psalm 58, 3, 8 , to be rescued from an enemy. 'The heavens relate...' To cross the sea or a river ch. 68, read on the sea." The main text begins with a heading on p. 68 and is in clear black ink, with dividing lines between each Psalm, which I identify according to the numeration of the Armenian Bible in curved brackets \{\} . The verses cited are sometimes corrupt, sometimes different from the Classical text, so the translations are direct and my own, rather than from the KJV or other standard translation:

"Chapter of the Psalm(s) of David. 'Blessed is the man who did not go' $\{1\}$. It is for planting trees and plants that they are not harmed, by God. 'Why are the heathens disturbed.' $\{2\}$ For when you go into court your cause will succeed. 'Lord, for many are they who have oppressed me." $\{3\}$ For counteracting ill will: read it and by God you will be free of all evil. 'When I called you heard me, God.' $\{4\}$ When you fall into straitened circumstances, read it and by God you will be freed. (69) 'Give ear to my words, O Lord.' $\{4\}$ For pain in the eyes. Read it over hot water and wash your face. You will be be freed by God. 'Lord, do not oppose me with your anger.' $\{6\}$ Concerning a witch. Read it 5 times over water for 3 days. Then wash yourself, and you will be freed by God. 'Lord my God, I have hoped in you, save.' For being afraid of a man. You will be freed by God. 'Lord, our Lord, for wondrous is the name.' $\{8\}$ For evil will against a man. You will be saved from him and he will not bother you anymore, by God. 'I will thank ${ }^{24}$ you Lord in all.' $\{9\}$ For other evil read this and you will be freed by God. (70) 'I hoped in you as you will say to my soul.' $\{10\}$ For an insane person. Read it over him or write it on a piece of raw canvas and keep it on his head: he will be freed by God. 'Save my life O Lord for I grow faint.' $\{11\}$ For a man deprived. When the deprive you, read it over rose oil and anoint your face and

possessions, in a bowl of water that is then guarded beneath the stars. Heaven opens that night, it is believed; and on the morn a girl takes each possession and reads out to its owner a quatrain predicting her fortunes in love and wedlock. This vichakakhagh, or "game of lots," is here distilled into a magical rite. See J.R. Russell, "Hārūt and Mārūt: The Armenian Zoroastrian Demonic Twins in the Qur'ān Who Invented Fiction," forthcoming in Proceedings of the Irano-Judaica conference, Hebrew University of Jerusalem, Oct. 2010, ed. J. Rubanovich and S. Shaked.

${ }^{23}$ Arm $h$. may abbreviate hator (volume); gl. abbreviates glux (chapter).

${ }^{24}$ Gohats 'uts' for Clas. Arm. gohats 'ayts', would be a Modern Arm. 3rd pers. sg. factitive "he satisfied" in place of a forgotten Clas. Arm. "I will thank"! 
hands and you will be freed by God. 'Till when, O Lord, do you forget me?' $\{12\}$ For robbers; and read it aloud that you be freed by God. 'The insensate one has said in his heart' $\{13\}$ is for matters of witchcraft of a man. Read it over water and give it to him to drink; he will be freed by God. ${ }^{25}$ (71) 'Lord, who will stand in your canopy?' $\{14\}$ This is for a crazed demon-possessed person. ${ }^{26}$ Set down a vessel of water, read this over it, warm it and wash that man: he will be freed by God. 'Listen, Lord of righteousness, and look' $\{16\}$ is for all snares and evil mischances. Read it and you will be freed by God. 'I will love you my Lord of power' $\{17\}$ is for all snares and harm. Read it and you will be freed by God. 'The Lord will hear you on the day of sorrow.' $\{19\}$ For success by God's command. 'Lord may he be glad in your power.' $\{20\}$ For enemies, that you may be freed by God. Renew. ${ }^{27}$ (72) 'God, my God, look upon me.' $\{21\}$ Against weapon and poisonous snake. Read it every morning that your affairs may prosper by God. 'God the earth with its fullness.' $\{23\}^{28}$ For snakes and scorpions, that they do not go and harm any man, by God. 'I called to you, Lord God' $\{27\}$ is for success and the day of evils. Read it 4 times: you will be freed by God from every evil. 'Judge for me, Lord, for I am accursed.' $\{25\}^{29}$ For a court case. It will succeed. Lord God. (73) 'The Lord is my light and my life.' $\{26\}$ For a thief. Read it five times a day to turn the thief away, by God's will. 'I called to you, Lord God.' $\{27\}$ For evil-wishers: write it on a goatskin. Hang it over the house and the evil-wisher will flee or go crazy by God. 'Approach the Lord God' $\{28\}$ is for wasting disease. Recite it over olive oil and smear it: he will be healed by God. $^{30}$ 'I exalt you Lord for receive.' $\{29\}$ For the sea: read it 3 times every day and travel fearlessly, by God."

The list resumes on p. 81 in scrawled pencil:

\footnotetext{
${ }^{25}$ Arm. vasn kaxardut'ean irats ' mardoy (for matters of witcheraft of a man) is an awkward construction, perhaps meaning that the Psalm has power over any manner of things caused by deviltry. The full verse of the Psalm protests that the fool in his heart says there is no God; so perhaps Armenians associated the black arts with atheist disbelief or belief only in powers other than the Almighty.

${ }^{26}$ Arm. vasn khevi ev divahari: khev is an epithet employed sometimes by ashughs, minstrels, with the specific sense of love-crazed; see James R. Russell, Yovhannes T'lkuranc' $i$ and the Mediaeval Armenian Lyric Tradition, Armenian Texts \& Studies Series 7 (Atlanta, GA: Scholars Press, 1987).

${ }^{27}$ Arm. Norogo stands alone on the last line of the page. My instinct was that the copyist had begun to write the hymn Norogogh tiezerats" (Renewer of the universe). But one cannot know.

${ }^{28}$ Arm. Tern, nom., instead of the gen. Tearn, "The earth is the Lord's and the fullness thereof..."

${ }^{29}$ Arm. yanetss, "in curses," is a startling misreading of yanbtsut 'ean (in unblemishedness)!

${ }^{30}$ The citation of the verse omits ordik ' (sons [of God])", whose literal meaning outside its idiomatic Hebrew context would surely have scandalized a believer in the Miatsin, SoleBegotten, Christ. Barak ts ' $a v$ is literally "thin pain"; and I read zeyt" eagh(in) as Tk. zeytinyağg, "olive oil".
} 
“Ch. 137, 'I will confess.' For trade and profit, read 7 times a day for 7 days. (82) Ch. 122, 'To you, Lord, I raised,' 2 times till 'Have mercy on us, O Lord, and have mercy' is for headaches that happen on one side. ${ }^{31}$ And write the talisman and keep it on your head. [Magical symbols] (83) Ch. 41, 'As he longs for the bride' till 'I said to God, I am acceptable.' Read 50 times and keep the talisman. [Magical symbols] (84) Ch. 59, 'God, you have rejected.' Recite till 'By your right hand and hear us.' Write the talisman. [Magical symbols] (85) Ch. 19, 'May God hear you.' Read 3 times and count your demands. They will be fulfilled immediately; and for headache read till 'We will greatly...' and keep this talis(man) on you. [Magical symbols] (86) Ch. 39, 'Rejoice.' [Magical symbols] Amen, amen. (87) Ch. 22, 'The Lord is my shepherd.' Read 7 times: sadness will turn to gladness and if you have business with a great $\operatorname{man}^{32}$ read it 7 times and go and ask and immediately he will fulfill or give. (88) Ch. 24, 'To you, Lord.' Read 3 times for a prisoner. He will be freed of all oppression. Take soil from beneath your foot and read over it 40 times, drop and scatter it. He will be freed."

Two loose, small pieces of paper were found inserted into the notebook. One, evidently in Mr. Nazarian's hand, is a slightly ungrammatical Classical Armenian Biblical imprecation, perhaps employed for magical purposes to ward off an enemy: Khavarests 'é ach ' $k$ ' nots 'ay zi mi tesanits'en (He will darken their eyes that they not see). This is in black pencil; on the reverse, in the purple ink of the section on remedies, is a more mundane text: a cure for hemorrhoids, with the ingredients of the medicine to be compounded listed in grams.

On another scrap of paper, in a careful but crude hand, is a short love poem that reminds one strongly of the hayrens attributed to the late mediaeval bard Nahapet K'uch'ak. It was probably originally a quatrain of ancient Armenian octosyllabic lines with a caesura at each hemistich; but the text is corrupt and full of misspellings: Du vard unis/ havet garun/ $k$ 'ukieank' $n$ i tel menayun/ es $i$ ayrunim im hok'u/ mej var menaun (You have a rose that is/ Eternal spring; your life/ Forever in your heart./ But I have fire in my soul/ That can never be put out). On the reverse of the slip is a recipe for a popular dessert called hat hat $p$ 'al luzayz (piece by piece) followed by unfamiliar words) calling for two cups each of cornstarch (nishe) and sugar, and three of water. This mixture is stirred in such a way that the resulting sweet crumbles like grains of rice.

To conclude, we may observe that the medical portion of the manuscript deals mostly with everyday complaints: constipation and hemorrhoids, migraine and stomach ache, and different kinds of poisoning; and the

\footnotetext{
31 That is, hemicranium: migraine.

32 The Arm. here mixes the pseudo-Classical with the thoroughly idiomatic: Ev mets mardoy het khndirk" mé unisnē. The last word would be in "standard" Modern Western, et'e unenas (if you have).
} 
remedies prescribed are of the sort that would have been easily and inexpensively available. Consultation of a physician is recommended only once; and every cure can be done at home. There is no reference to surgery, no recourse to specialized medical instruments. So this part of the manuscript probably was used. The two magical sections of spells and Psalms focus on love and marriage, court cases and one's reputation and image, counteracting the ill will and machinations of enemies, head and chest pain again, and the thieves and perilous conditions at sea or on the road that beset the traveler. From the urbane, sophisticated image of Mr. Nazarian that we have, it is most unlikely that having copied the talismans, he employed them to concoct potions, mutter dire spells to destroy foes, or perform lecanomantic rites to woo women. Use of a magic bowl for such a purpose, one imagines, might have earned him a smart bat on the head from an irate wife wielding a wholly unmagical frying pan. His curiosity about the occult is of a diffident sort many of an intellectual bent share-I am writing this study, am I not - so it was sufficient to engage his writing hand; but one thinks he kept the darker forces of the supernatural at arm's length.

Recitation of the Psalms was probably another matter. It is common for printed editions of the Narek, the Book of Lamentations of St. Grigor Narekats' $i$, the tenth-century mystical poet-theologian, to contain a list of chapters to be prayed for this or that purpose; and owners of these books frequently added lists of their own. I have several such, large and small, from the 18th to the 20th century, in my own collection. Christian and Jewish believers resort to the help of the Psalms for comfort in grief, help in healing, relief from fear, and reassurance in the face of enmity. I have done so myself, in sickness and in health. So Mr. Nazarian might have used this list, too. Again, one would imagine that he did not employ everything he copied; and he mentions only a quarter or so of the hundred-and-fifty Psalms; so perhaps he had only a partial manuscript, or his notebook was coming to an end, or he was just tired.

It is not clear what the magical symbols he copied, sometimes assiduously, sometimes it would seem a bit more playfully or carelessly, meant to him. He uses only one symbol or abbreviation, an X with four dots, one in each angle, in the text itself. He surely understood the Arabic numbers and individual letters of the Arabic alphabet that appear; but the rest of the symbols, whether rising from a base line or inscribed freely in space, do not seem to have any translatable meaning and never did, although many of them have been systematically employed in Armenian cryptograms. The bulk of them, with the obvious exception of permutated letters of the Armenian alphabet, seem to derive from Muslim magical texts, where they have no linguistic sense either.

None of the spells touches upon any achievement of technology of the last two centuries; though the medical portion does mention cocaine, a recent import to the Near East. Although recent editions of the Armenian Erazahan, 
or book of interpretation of dreams, incorporate the images of recent inventions: telephones, trains, air travel, electric lights, and so on-we do not find them here. Travel is only by sea. The setting seems to be that of a rural village: one buries magic bowls in fields, not on the crossroads of 187th Street and St. Nicholas Avenue. ${ }^{33}$ Still, not much has changed in the human condition, perhaps. Travel is more common, and faster; but it still has its dangers. A number of Psalms are addressed to the insane, the lovesick, the possessed, the depressed. Sigmund Freud died in 1939, less than a decade after our manuscript traveled by sea to the New World; but most people beset by the sorrows of life still confided their troubles, not to a psychiatrist, but to God or loving friends and family. Society was kinder, and more respectful, to the elderly; but the young still clamored for excitement and passion. I close the book, return to these latter days, and wonder whether we have really come so far. Genocide did not end with the Armenians and the Jews, but became an increasingly common instrument of state policy; and people were as indifferent to the recent Rwandan slaughter as it was happening as they were to Auschwitz. Have texting, Prozac, and Ritalin really ameliorated human loneliness and sorrow? The warm kitchen, the cup of coffee, the actual and not virtual face of a trusted friend or loved relative, seem to me more authentic and less alienating. Mr. Nazarian's cures, like the other treasures of his little library, are quaint but perhaps not wholly obsolete.

HARVARD UNIVERSITY

\footnotetext{
${ }^{33}$ Ironically, perhaps, a different kind of witchcraft, as a part of the Afro-Caribbean Santería religion, does thrive in the neighborhood; and implements of the craft can be purchased at numerous shops called botanicas.
} 